\title{
Occurrence of Batrachochytrium dendrobatidis in anurans of the Mediterranean region of Baja California, México
}

\author{
Anny Peralta-García ${ }^{1,2, *}$, Andrea J. Adams ${ }^{3}$, \\ Cheryl J. Briggs ${ }^{3}$, Patricia Galina-Tessaro ${ }^{1}$, Jorge H. Valdez-Villavicencio ${ }^{2}$, \\ Bradford D. Hollingsworth ${ }^{4}$, H. Bradley Shaffer ${ }^{5}$, Robert N. Fisher ${ }^{6}$ \\ ${ }^{1}$ Centro de Investigaciones Biológicas de Noroeste, La Paz, Baja California Sur 23096, México \\ ${ }^{2}$ Conservación de Fauna del Noroeste, Ensenada, Baja California 22785, México \\ ${ }^{3}$ Department of Ecology, Evolution and Marine Biology, University of California, Santa Barbara, California 93106, USA \\ ${ }^{4}$ Department of Herpetology, San Diego Natural History Museum, San Diego, California 92101, USA \\ ${ }^{5}$ Department of Ecology and Evolutionary Biology, and La Kretz Center for California Conservation Science, \\ Institute of the Environment and Sustainability, University of California, Los Angeles, California 90095, USA \\ ${ }^{6}$ US Geological Survey, Western Ecological Research Center, San Diego, California 92101, USA
}

\begin{abstract}
Chytridiomycosis is caused by the fungal pathogen Batrachochytrium dendrobatidis $(B d)$ and is regarded as one of the most significant threats to global amphibian populations. In México, $B d$ was first reported in 2003 and has now been documented in 13 states. We visited 33 localities and swabbed 199 wild-caught anurans from 7 species ( 5 native, 2 exotic) across the Mediterranean region of the state of Baja California. Using quantitative PCR, $B d$ was detected in 94 individuals ( $47.2 \%$ of samples) at 25 of the 33 survey localities for 5 native and 1 exotic frog species. The exotic Xenopus laevis was the only species that tested completely negative for $B d$. We found that remoteness, distance to agricultural land, and elevation were the best positive predictors of $B d$ presence. These are the first $B d$-positive results for the state of Baja California, and its presence should be regarded as an additional conservation threat to the region's native frog species.
\end{abstract}

KEY WORDS: Chytridiomycosis $\cdot$ Northwestern México $\cdot$ Amphibians $\cdot$ Diseases $\cdot$ Threats

\section{INTRODUCTION}

Chytridiomycosis, an infectious disease caused by the fungal pathogen Batrachochytrium dendrobatidis $(B d)$, represents one of the most significant threats to global amphibian populations and is among the most lethal diseases affecting vertebrates (Skerratt et al. 2007). The impact of $B d$ on amphibian populations is highly variable and has been associated with several environmental and human-mediated factors, including temperature, precipitation, climate change, and habitat loss or alteration (Bosch et al. 2007, Andre et al. 2008, Raffel et al. 2015). As a result, some species

\footnotetext{
*Corresponding author: annyperaltagarcia@yahoo.com.mx
}

and populations infected with $B d$ suffer massive declines, others appear to be more tolerant, and still others continue to be impacted even once $B d$ has reached an enzootic state (Daszak et al. 2004, Briggs et al. 2005, Fisher \& Garner 2007, Catenazzi et al. 2017). Bd-tolerant species may act as biological reservoirs, and have been linked to the probable spread of the pathogen (Reeder et al. 2012, Huss et al. 2013).

In México, $B d$ was first reported in 2003, and has been detected since then in wild amphibian populations from the states of Baja California Sur, Chiapas, Guerrero, Hidalgo, Estado de México, Michoacán,

(C) The authors and outside the USA the US Government 2018. Open Access under Creative Commons by Attribution Licence. Use, distribution and reproduction are unrestricted. Authors and original publication must be credited.

Publisher: Inter-Research · www.int-res.com 
Morelos, Oaxaca, Puebla, Sonora, Tamaulipas, Veracruz, and Distrito Federal (Mendoza-Almeralla et al. 2015). Bd outbreaks have been identified as a likely cause for amphibian declines in central and southern México (Lips et al. 2004, Cheng et al. 2011). In the 2 states that comprise the Baja California peninsula of México, a survey for $B d$ in the native treefrogs $H y l i-$ ola regilla and $H$. cadaverina at 3 survey localities tested negative (Frías-Alvarez et al. 2008). In subsequent surveys, $H$. regilla in isolated oasis populations in Baja California Sur were positive for Bd (Luja et al. 2012). In adjacent California (USA), $B d$ has been detected in both native and exotic anuran species, and has been linked to severe declines in montane and foothill populations of ranid species (Rachowicz et al. 2006, Briggs et al. 2010, Adams et al. 2017a). Six anuran species native to the California Mediterranean region extend into Baja California: Rana draytonii, $H$. regilla, $H$. cadaverina, Anaxyrus boreas, A. californicus, and Spea hammondii. All of these species have tested positive for $B d$ in California (Lannoo et al. 2011, Piovia-Scott et al. 2011, Adams et al. 2017a, R. N. Fisher \& A. Backlin unpubl. data), with massive die-offs observed for $A$. boreas (Colorado populations, Muths et al. 2003), and tolerance suggested for $R$. draytonii and $H$. regilla in California (Padgett-Flohr 2008, Reeder et al. 2012).

Although $\mathrm{Bd}$ models suggest that hosts in Mediterranean forest, woodlands, and scrub may have the lowest probabilities of $B d$ infection (Olson et al. 2013), amphibian declines have been documented in this region within California (Jennings \& Hayes 1994, Adams et al. 2017a), suggesting that $B d$ may still be a cause for conservation concern (Vojar et al. 2017). Here, we report on the presence of $B d$ in native and exotic anurans across the Mediterranean region of Baja California, and discuss its importance as a potential threat to their populations.

\section{MATERIALS AND METHODS}

\section{Sample collection}

During fieldwork conducted in spring 2013 and 2014, we swabbed amphibians in several arroyos in the Baja California Mediterranean region, from the US-México border south to Arroyo Santo Domingo, at elevations from sea level to $2070 \mathrm{~m}$. We visited 33 localities and swabbed 199 individual anurans representing 5 genera and 7 species (see Table 1). For each site, we gathered data on elevation, distance to the nearest edge of an urban area (as a measure of remoteness), percentage of natural habitat within a $3 \mathrm{~km}$ buffer, and distance to the nearest edge of agricultural land, using Google Earth (http://earth. google.com; last accessed in April 2016). To collect $B d$ samples, we followed the technique described by Hyatt et al. (2007), using sterile rayon-tipped swabs (Medical Wire and Equipment). Each swab was preserved and stored in $95 \%$ ethanol and then dried to evaporate all residual ethanol prior to DNA extraction.

\section{Molecular methods}

DNA from swabs was extracted by adding $40 \mu \mathrm{l}$ of PrepMan ${ }^{\circledR}$ Ultra (Applied Biosystems) and incubating at $100^{\circ} \mathrm{C}$ for $10 \mathrm{~min}$. Tubes were then centrifuged at $13000 \times g$ for $3 \mathrm{~min}$, and the supernatant was aspirated from swabs and placed in a new, sterile $1.5 \mathrm{ml}$ tube. Samples were diluted 1:10 with sterile, DNasefree $0.25 \times$ TE (Tris-EDTA). The qPCR analysis was performed on an Applied Biosystems StepOnePlus ${ }^{\mathrm{TM}}$ Real-Time PCR System, and PCR reactions and amplification parameters followed Boyle et al. (2004). Positive controls in quantities of $100,10,1$, and 0.1 zoospores were run on each plate in triplicate, in addition to triplicate negative controls, and were used to create the standard curve. DNA from $B d$ used as standard DNA was developed by Mary Toothman, University of California, Santa Barbara, USA (isolate CJB7, from California, USA; ITS copy number $=60$ ). Standards were quality-controlled for equivalent standard quantification to isolate AAHL 98 1810/3 prior to use in qPCR using a hemocytometer. To account for the dilution of the $B d$ extract and calculate the total amount of $B d$ DNA per swab, raw genomic output from qPCR results was multiplied by 80 to obtain a total number of zoospore equivalents (ZE) per swab. ZE can be used as an index of the intensity of infection or ' $B d$ load' for individual frogs sampled.

\section{Statistical analysis}

To examine which factors best predict $B d$ load and prevalence in amphibians sampled, we used generalized linear mixed-effects models (GLMMs). With the GLMMs, we were able to account for non-independence of samples with the use of a variable ('survey event'), created to group frogs sampled within the same 2 wk time period and at the same site as a random effect. We excluded samples $(n=3)$ that 
were represented by 1 sample within a random effect level, and Xenopus laevis samples $(\mathrm{n}=9)$ because they were all negative and therefore prevented model convergence; including these samples did not change our fundamental results. We included only $B d$-positive samples (ZE $>0$ ) in the $B d$ load analysis and log-transformed those ZE values. We hypothesized that $B d$ prevalence and load would vary with species, distance to agricultural land, elevation, percentage of natural area within a $3 \mathrm{~km}$ buffer, and remoteness (calculated as distance to the nearest town). We developed these hypotheses based on the literature, which suggests that $B d$ prevalence and load increase with elevation and vary by species and degree of habitat alteration (Becker \& Zamudio 2011, Johnson et al. 2011, Saenz et al. 2015). We z-transformed all 4 continuous predictor variables so that effect sizes of different predictors were comparable. We ranked models according to Akaike's information criterion, corrected for small sample sizes $\left(\mathrm{AIC}_{\mathrm{c}}\right)$ to determine the relative importance of predictor variables within each set of models (one set for $B d$ presence-absence and one for $B d$ load). We conducted all analyses in the R computing environment (version 3.3.2, R Development Core Team 2016).

\section{RESULTS}

We detected $B d$ in 94 individuals (47.2\% of samples) at 25 of the 33 survey localities (Table 1, Fig. 1). Bd was present in Anaxyrus californicus, A. boreas, Hyliola cadaverina, H. regilla, Rana draytonii, and $R$. catesbeiana. We did not observe any

Table 1. Sites where amphibians were sampled for Batrachochytrium dendrobatidis $(B d)$ presence. Site ID refers to numbers in Fig. 1. n: number of sampled individuals; Pr: $B d$ prevalence, defined as the fraction of infected individuals; mean $B d$ load: number of zoospores per infected individual; a.s.l.: above sea level; Ua: distance to nearest urban area; Al: distance to nearest agriculture land

\begin{tabular}{|c|c|c|c|c|c|c|c|}
\hline $\begin{array}{l}\text { Site } \\
\text { ID }\end{array}$ & Locality & $\mathrm{n}$ & $\operatorname{Pr}(\%)$ & $\begin{array}{l}\text { Mean } \\
B d \text { load }\end{array}$ & $\begin{array}{c}\text { Elevation } \\
\text { (m a.s.l.) }\end{array}$ & $\begin{array}{c}\mathrm{Ua} \\
(\mathrm{km})\end{array}$ & $\begin{array}{c}\mathrm{Al} \\
(\mathrm{km})\end{array}$ \\
\hline 1 & Abelardo L. Rodríguez Dam, Tijuana & 1 & 0 & 0 & 118 & 0 & 22.0 \\
\hline 2 & El Carrizo Dam, Tijuana & 1 & 100 & 925.21 & 272 & 1.0 & 8.0 \\
\hline 3 & Rancho las dos Cumbres, Tecate & 2 & 0 & 0 & 620 & 1.0 & 0.1 \\
\hline 4 & Cañón El Alamo, Reserva Kumiai & 6 & 17 & 9.26 & 488 & 9.0 & 8.4 \\
\hline 5 & El Gato, Cañón Las Parras, Ejido Guadalajara & 1 & 100 & 3150.67 & 855 & 15.0 & 16.5 \\
\hline 6 & Rancho Talegas Arroyo las Calabazas & 2 & 0 & 0 & 1187 & 21.0 & 23.3 \\
\hline 7 & Rancho San Faustino, Sierra Juárez & 4 & 50 & 175.66 & 1270 & 25.0 & 25.0 \\
\hline 8 & Cañada El Morro, Rosarito & 9 & 0 & 0 & 5 & 0 & 0.4 \\
\hline 9 & La Misión, Arroyo Guadalupe & 10 & 20 & 6034.86 & 1 & 0 & 0.1 \\
\hline 10 & Cañada Salsipuedes & 6 & 50 & 229.84 & 125 & 9.0 & 2.1 \\
\hline 11 & Rancho Madrigal, Ensenada & 1 & 100 & 6.13 & 300 & 0 & 7.5 \\
\hline 12 & Cañada Miracielo, San Antonio de las Minas & 5 & 20 & 1.57 & 358 & 6.6 & 6.8 \\
\hline 13 & Cañón Agua Caliente, Valle de Guadalupe & 6 & 17 & 163.92 & 390 & 7.5 & 1.5 \\
\hline 14 & Arroyo El Barbon, Cañón Hondo & 2 & 0 & 0 & 625 & 5.0 & 2.7 \\
\hline 15 & Rancho la Casa Verde, Arroyo Casa Verde & 3 & 0 & 0 & 1370 & 20.0 & 20.1 \\
\hline 16 & Arroyo San Carlos, Ensenada & 5 & 80 & 387.64 & 70 & 2.3 & 0.5 \\
\hline 17 & Rancho Agua Caliente, Arroyo Santo Tomas & 1 & 0 & 0 & 495 & 19.0 & 7.8 \\
\hline 18 & Rancho Agua Caliente, Arroyo San Vicente & 9 & 0 & 0 & 218 & 13.6 & 1.8 \\
\hline 19 & San Rafael, near junction of Arroyo La Palmita & 20 & 30 & 1819.58 & 220 & 23.5 & 0.5 \\
\hline 20 & San Rafael (35 km E of Colonet) & 2 & 50 & 1.93 & 340 & 29.8 & 11.0 \\
\hline 21 & San Rafael, 3 km NW of Mike's Sky Ranch & 6 & 33 & 26.76 & 1036 & 30.0 & 24.5 \\
\hline 22 & Rancho Meling, Sierra San Pedro Mártir & 9 & 89 & 265.75 & 620 & 40.0 & 15.5 \\
\hline 23 & Rancho El Molino, Sierra San Pedro Mártir & 4 & 25 & 0.807 & 555 & 35.0 & 14.2 \\
\hline 24 & Santo Domingo, near Rancho La Canastilla & 6 & 33 & 2.54 & 145 & 14.0 & 11.5 \\
\hline 25 & $6 \mathrm{~km}$ downstream of Rancho Valladares & 5 & 40 & 220.93 & 635 & 26.0 & 23.5 \\
\hline 26 & Rancho Valladares, Sierra San Pedro Mártir & 11 & 82 & 165.30 & 720 & 30.0 & 27.0 \\
\hline 27 & Rancho El Potrero, Sierra San Pedro Mártir & 7 & 57 & 8.98 & 890 & 37.0 & 35.0 \\
\hline 28 & Cañón La Jolla, Sierra San Pedro Mártir & 3 & 100 & 1369.90 & 1560 & 43.8 & 30.9 \\
\hline 29 & Arroyo San Antonio Murillos & 11 & 64 & 146.75 & 560 & 35.5 & 33.5 \\
\hline 30 & Rancho San Isidoro, Sierra San Pedro Mártir & 4 & 100 & 2452.96 & 920 & 42.5 & 39.3 \\
\hline 31 & Arroyo La Víbora, Sierra San Pedro Mártir & 5 & 60 & 2764.70 & 1880 & 46.6 & 44.5 \\
\hline 32 & Rancho Viejo, Sierra San Pedro Mártir & 7 & 28 & 146.75 & 2050 & 51.0 & 65.0 \\
\hline 33 & La Grulla, Sierra San Pedro Mártir & 25 & 92 & 379.28 & 2070 & 51.6 & 50.0 \\
\hline
\end{tabular}




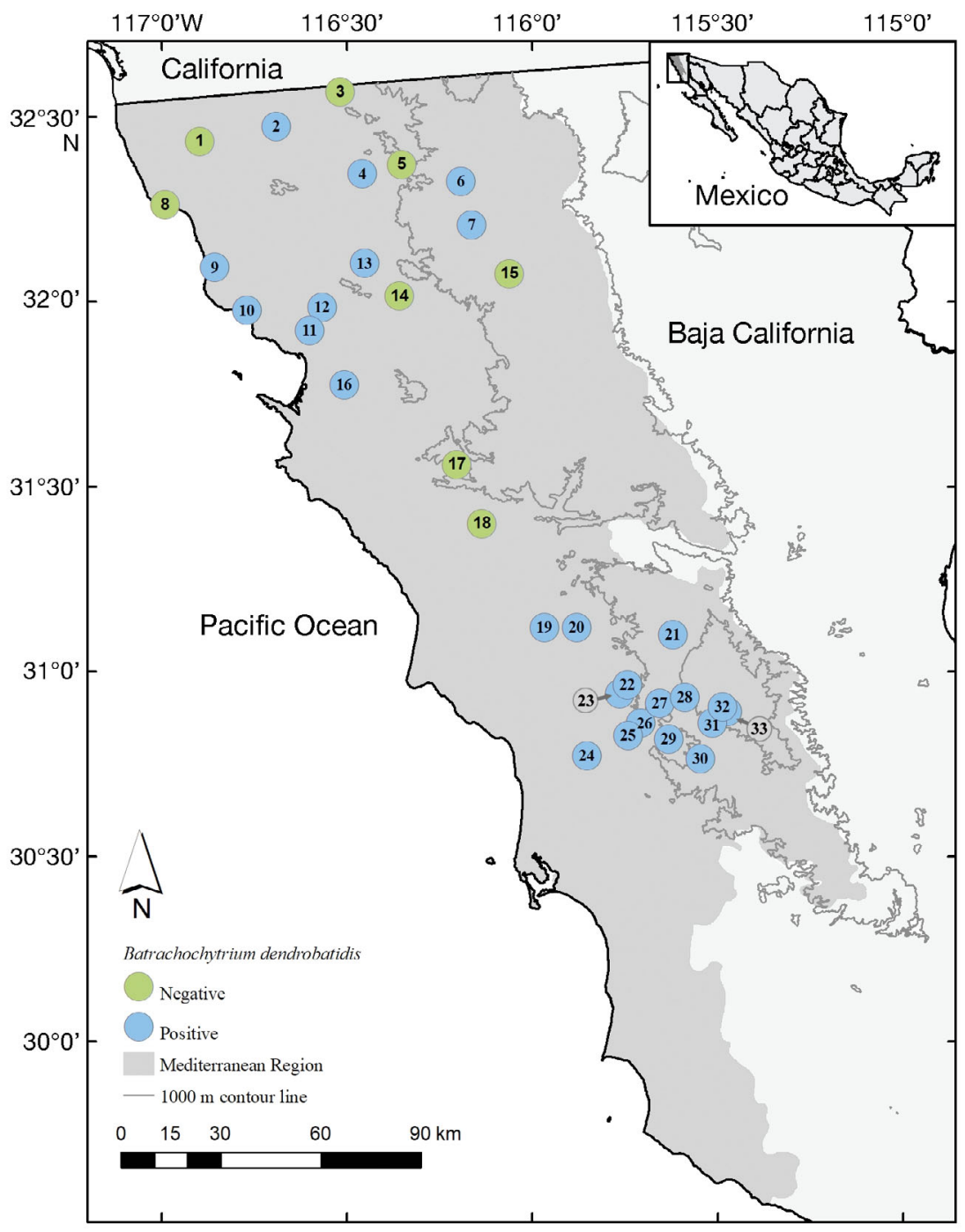

Fig. 1. Survey localities in the Mediterranean region of Baja California, México, and whether the amphibians sampled there tested positive or negative for Batrachochytrium dendrobatidis (inset: México). Numbers are site IDs (see Table 1)

Spea hammondii during our surveys; thus, information is still lacking for this species. Only the exotic Xenopus laevis, tested on 9 individuals from a single urban locality, was $B d$-negative. $B d$ loads varied from zero ZE (i.e. no evidence of infection) to $12067 \mathrm{ZE}$ in an adult $H$. regilla from La Misión (Site 9). Across all sampling sites, $R$. catesbeiana exhibited the highest $B d$ prevalence $(75 \%)$, followed by $R$. draytonii $(68 \%)$ and $A$. boreas $(40 \%)$ (Table 2). $B d$ loads were highest in $H$. cadaverina (mean ZE: 1634) and H. regilla (mean ZE: 1234), and lowest in $A$. boreas (mean ZE: 35). Bd-positive sites occurred at elevations ranging from sea level (i.e. Salsipuedes and La Misión) to $2070 \mathrm{~m}$ (i.e. La Grulla in the Sierra San Pedro Mártir). Bd-positive sites also ranged from immediately adjacent to urban areas up to $51.6 \mathrm{~km}$ away from the nearest town (Table 1). The best-fit models of $B d$ presenceabsence indicated positive effects of remoteness, distance from agriculture, and elevation (Tables $3 \& 4$ ). None of the $B d$ load models were improved by predictors beyond the intercept-only model (Table 5). Despite differences, species was not a significant predictor of either $B d$ prevalence or load in the GLMMs (Tables 3 \& 5).

\section{DISCUSSION}

Our results indicate that $B d$ is widespread in most native anurans in the Mediterranean region of Baja California (Spea hammondii is still untested), and should be considered a potential threat to these anuran communities. We found $B d$ at sites from the coast to the mountains, in areas close to urban centers, and in remote, pristine habitats. Consistent with our expectations, $B d$ prevalence was positively associated with remoteness, distance to agricultural land, and elevation. High-elevation amphibian populations have been among the most affected by chytridiomycosis, as $B d$-related die-offs have been documented in many montane regions (Stuart et al. 2004, Rachowicz et al. 2006, Bosch et al. 2007, Cheng et al. 2011). At our highest elevation site, and one of the most remote (also one of our most pristine) - La Grulla at $2070 \mathrm{~m}, B d$ prevalence was $92 \%$, and mean ZE was 195. Even though no massive die-offs have been observed at La Grulla or other locations, this could be the result of a lack of population monitoring. In addition, $B d$ die-offs can be abrupt events, so the probability of observing dead or dying animals is low in remote, infrequently visited regions (Piovia-Scott et al. 2011).

Our observation that $B d$ prevalence increases with distance to agricultural land and distance from the nearest town is consistent with previous work that suggests $B d$ is sensitive to temperature and moisture gradients introduced by more managed 
Table 2. Amphibian species sampled for Batrachochytrium dendrobatidis $(B d)$ presence. n: sample size; Pr: $B d$ prevalence; ZE: zoospore equivalents (mean $\pm \mathrm{SD}$ ). See Fig. 1, Table 1 for site IDs

\begin{tabular}{|lcccl|}
\hline Species & $\mathrm{n}$ & $\operatorname{Pr}(\%)$ & ZE $\left(\right.$ ind. $\left.^{-1}\right)$ & Site ID(s) \\
\hline Anaxyrus boreas & 5 & 40 & $35.9 \pm 50.3$ & $1,7,33$ \\
A. californicus & 14 & 36 & $147.5 \pm 321.6$ & $15,18,19,20,24,26$ \\
Hyliola cadaverina & 49 & 39 & $1634.5 \pm 2848.2$ & $4,6,10,14,15,18-21,23-25,28-31$ \\
H. regilla & 46 & 35 & $1234.8 \pm 3023.1$ & $2-5,7,9,10,12,13,16-19,21,23,24,29,32,33$ \\
Rana draytonii & 68 & 68 & $284.1 \pm 1247.6$ & $19,22,24-27,29,33$ \\
R. catesbeiana & 8 & 75 & $259.8 \pm 354.3$ & $9,11,12,16$ \\
Xenopus laevis & 9 & 0 & 0 & 8 \\
\hline
\end{tabular}

Table 3. Candidate mixed effects models used to determine the best predictors of Batrachochytrium dendrobatidis presence in sampled amphibians. $\mathrm{AIC}_{\mathrm{c}}$ : Akaike's information criterion corrected for small sample sizes

\begin{tabular}{|llcccc|}
\hline $\begin{array}{l}\text { Model } \\
\text { rank }\end{array}$ & Model & $\begin{array}{c}\text { No. of } \\
\text { parameters }\end{array}$ & $\mathrm{AIC}_{\mathrm{c}}$ & $\Delta \mathrm{AIC}_{\mathrm{c}}$ & Weight \\
\hline 1 & Distance from agriculture & 3 & 218.45 & 0.00 & 0.37 \\
2 & Remoteness & 3 & 218.82 & 0.37 & 0.30 \\
3 & Elevation & 3 & 220.04 & 1.59 & 0.17 \\
4 & Intercept only & 2 & 220.73 & 2.28 & 0.12 \\
5 & Natural area & 3 & 222.80 & 4.35 & 0.04 \\
6 & Species & 7 & 226.32 & 7.87 & 0.01 \\
\hline
\end{tabular}

Table 4. Parameter estimates for best-fit models (within $2 \mathrm{AIC}_{\mathrm{c} i}$ see Table 3) used to determine the best predictors of Batrachochytrium dendrobatidis presence/absence in amphibians. $\mathrm{AIC}_{\mathrm{c}}$ : Akaike's information criterion corrected for small sample sizes. ${ }^{*} \mathrm{p}<0.05$

\begin{tabular}{|llrrrl|}
\hline $\begin{array}{l}\text { Model } \\
\text { rank }\end{array}$ & Parameter & Estimate & SE & $Z$ & $\mathrm{p}$ \\
\hline 1 & (intercept) & -0.37 & 0.32 & -1.15 & 0.25 \\
& Distance from agriculture & 0.70 & 0.33 & 2.14 & $0.03^{*}$ \\
2 & (intercept) & -0.32 & 0.33 & -0.97 & 0.33 \\
& Remoteness & 0.63 & 0.32 & 1.90 & 0.05 \\
3 & (intercept) & -0.35 & 0.34 & -1.04 & 0.30 \\
& Elevation & 0.54 & 0.33 & 1.64 & 0.10 \\
\hline
\end{tabular}

Table 5. Candidate mixed effects models used to determine the best predictors of Batrachochytrium dendrobatidis load in sampled amphibians. AICc: Akaike's information criterion corrected for small sample sizes

\begin{tabular}{|llcccc|}
\hline $\begin{array}{l}\text { Model } \\
\text { rank }\end{array}$ & Model & $\begin{array}{c}\text { No. of } \\
\text { parameters }\end{array}$ & $\mathrm{AIC}_{\mathrm{c}}$ & $\Delta \mathrm{AIC}_{\mathrm{c}}$ & Weight \\
\hline 1 & Distance to agriculture & 4 & 455.12 & 0.00 & 0.40 \\
2 & Intercept only & 3 & 456.15 & 1.04 & 0.24 \\
3 & Elevation & 4 & 457.18 & 2.06 & 0.14 \\
4 & Remoteness & 4 & 457.42 & 2.31 & 0.13 \\
5 & Natural area & 4 & 457.88 & 2.76 & 0.10 \\
6 & Species & 8 & 463.83 & 8.71 & 0.01 \\
\hline
\end{tabular}

environments (Murrieta-Galindo et al. 2014, Saenz et al. 2015). Habitat loss has been inversely associated with $B d$ prevalence and load in the tropics, likely a result of microclimatic conditions caused by habitat alteration that inhibit $B d$ growth and persistence (Becker \& Zamudio 2011). Similar results have been reported for anuran populations in Veracruz, México with higher $B d$ prevalence in native forest than agricultural fields (Murrieta-Galindo et al. 2014). In addition, infection may be associated with amphibian species richness, which is likely to be lower in more disturbed habitats (Saenz et al. 2015). Some pesticides may suppress amphibian immune defenses and may facilitate disease outbreaks (Davidson et al. 2007). Amphibian declines in California have been related to agricultural chemicals (Davidson et al. 2002), and pesticides or fertilizers may also affect $B d$ zoospores (Johnson et al. 2003, McMahon et al. 2013b), although the causal role of pesticides on $B d$ susceptibility remains largely unknown. Only 8 of 33 localities in this study were $B d$-negative, although 5 of these sites contained small sample sizes $(\mathrm{n}<5)$ and should not be considered conclusively $B d$-negative. Two $B d$-negative sites, Arroyo Santo Tomas $(\mathrm{n}=1)$ and Arroyo San Vicente $(\mathrm{n}=9)$, contain hot springs, and their higher water temperatures may inhibit $B d$ growth and infection (Forrest \& Schlaepfer 2011). Both Anaxyrus species showed the lowest ZE values, potentially related to the primarily terrestrial life history strategies of these 2 species, which may reduce the risk of infection.

Rana catesbeiana and Xenopus laevis are known to be tolerant carriers of $B d$ and therefore have the potential to vector $B d$ to 
susceptible native amphibians (Greenspan et al. 2012, Vredenburg et al. 2013). In the present study, $R$. catesbeiana individuals were $B d$-positive at 4 of 5 sites (Table 2), while $X$. laevis individuals from our single collection locality were $B d$-negative. Since $R$. catesbeiana and $X$. laevis were only found at 6 of our 33 sites, it appears unlikely these species are the primary vector spreading $B d$ in Baja California, even though $R$. catesbeiana may be acting as a $B d$ reservoir host in the areas where it is sympatric with native amphibians (Adams et al. 2017b). Recent work has suggested that non-amphibian vectors, including crayfish, birds, and even rainwater, may have played an important role in the emergence and spread of $B d$ (McMahon et al. 2013a, Kolby et al. 2015).

Other $B d$ carriers may include native amphibians, particularly Hyliola regilla, a mobile, common species characterized by large upland foraging sites, multiple breeding ponds, and extensive movement between ponds and streams (Schaub \& Larsen 1978). A retrospective analysis of museum specimens has shown that $B d$ occurrences in central California are associated with the presence of infected $H$. regilla (Padgett-Flohr \& Hopkins 2009), and this species may act as a $B d$ reservoir, given its high $B d$ tolerance (Reeder et al. 2012). In the present study, mean ZE for both Hyliola species were the highest of any species sampled (H. cadaverina: 1634 mean $\mathrm{ZE}$; $H$. regilla: 1234 mean $\mathrm{ZE}$; Table 2). Also, the highest $\mathrm{ZE}$ value on an individual in this study was from $H$. regilla (12 000 ZE at La Misión), which is within the range of values considered lethal in $R$. muscosa, $R$. sierrae, and Lithobates areolatus (>10 $000 \mathrm{ZE}$; Vredenburg et al. 2010, Kinney et al. 2011). Further work is needed to determine how both hylid species might be playing a role in carrying and transmitting $B d$ to other amphibians in the region.

We suggest that our initial surveys be followed with regular monitoring to determine the fate of these sensitive amphibian populations and to understand and manage for the dynamics and effects of $B d$ infection in the Mediterranean region of Baja California. In addition, the genetic identity of $B d$ in the region is currently unknown, and low prevalence might also be related to the presence of a less virulent strain than the global panzootic lineage of $B d$, which has been responsible for declines and extinctions elsewhere in the world (Farrer et al. 2011). Until this is clarified, we suggest that any fieldwork conducted in the region include adequate decontamination and hygiene protocols to avoid $B d$ transmission between aquatic sites.
Acknowledgements. We thank Adam Backlin, Jonathan Richmond, Elizabeth Gallegos, Clark Mahrdt, Daniela López, Gustavo Danemann, and the staff of the Parque Nacional Sierra San Pedro Mártir. Funding was provided by the JiJi Foundation, International Community Foundation, Pronatura Noroeste, and University of California Institute for México and the United States (UC-Mexus). We give special thanks to the Binational Advisory Board at the San Diego Natural History Museum for their interest and encouragement. A.P.G. was a recipient of a doctoral fellowship from Consejo Nacional de Ciencia y Tecnología (CONACYT CVU 221150). Collecting permits were issued by the Secretaría del Medio Ambiente y Recursos Naturales to P.G.T. (SGPA/DGVS/01458/13 and SGPA/DGVS/02658/14). This is contribution number 610 of the US Geological Survey Amphibian Research and Monitoring Initiative (ARMI). Any use of trade, product, website, or firm names in this publication is for descriptive purposes only and does not imply endorsement by the US government.

\section{LITERATURE CITED}

Adams AJ, Pessier AP, Briggs CJ (2017a) Rapid extirpation of a North American frog coincides with an increase in fungal pathogen prevalence: historical analysis and implications for reintroduction. Ecol Evol 7:10216-10232

Adams AJ, Kupferberg SJ, Wilber MQ, Pessier AP and others (2017b) Extreme drought, host density, sex, and bullfrogs influence fungal pathogen infection in a declining lotic amphibian. Ecosphere 8:e01740

Andre SE, Parker J, Briggs CJ (2008) Effect of temperature on host response to Batrachochytrium dendrobatidis infection in the mountain yellow-legged frog (Rana muscosa). J Wildl Dis 44:716-720

* Becker CG, Zamudio KR (2011) Tropical amphibian populations experience higher disease risk in natural habitats. Proc Natl Acad Sci USA 108:9893-9898

* Bosch J, Carrascal LM, Duran L, Walker S, Fisher MC (2007) Climate change and outbreaks of amphibian chytridiomycosis in a montane area of central Spain; is there a link? Proc R Soc B 274:253-260

Boyle DG, Boyle DB, Olsen V, Morgan JAT, Hyatt AD (2004) Rapid quantitative detection of chytridiomycosis (Batrachochytrium dendrobatidis) in amphibian samples using real-time Taqman PCR assay. Dis Aquat Org 60: 141-148

* Briggs CJ, Vredenburg VT, Knapp RA, Rachowicz LJ (2005) Investigating the population-level effects of chytridiomycosis, a fungal disease of amphibians. Ecology 86: 3149-3159

Briggs CJ, Knapp RA, Vredenburg VT (2010) Enzootic and epizootic dynamics of the chytrid fungal pathogen of amphibians. Proc Natl Acad Sci USA 107:9695-9700

Catenazzi A, Swei A, Finkle J, Foreyt E and others (2017) Epizootic to enzootic transition of a fungal disease in tropical Andean frogs: Are surviving species still susceptible? PLOS ONE 12:e0186478

* Cheng TL, Rovito SM, Wake DB, Vredenburg VT (2011) Coincident mass extirpation of neotropical amphibians with the emergence of the infectious fungal pathogen Batrachochytrium dendrobatidis. Proc Natl Acad Sci USA 108:9502-9507

Daszak P, Strieby A, Cunningham AA, Longcore JE, Brown CC, Porter D (2004) Experimental evidence that the bull- 
frog (Rana catesbeiana) is a potential carrier of chytridiomycosis, an emerging fungal disease of amphibians. Herpetol J 14:201-207

* Davidson C, Shaffer HB, Jennings MR (2002) Spatial tests of the pesticide drift, habitat destruction, UV-B, and climate change hypotheses for California amphibian declines. Conserv Biol 16:1588-1601

Wavidson C, Benard MF, Shaffer HB, Parker JM, O'Leary C, Conlon JM, Rollins-Smith LA (2007) Effects of chytrid and carbaryl exposure on survival, growth and skin peptide defenses in foothill yellow-legged frogs. Environ Sci Technol 41:1771-1776

FFarrer RA, Weinert LA, Bielby J, Garner TW and others (2011) Multiple emergences of genetically diverse amphibian-infecting chytrids include a globalized hypervirulent recombinant lineage. Proc Natl Acad Sci USA 108:18732-18736

Fisher MP, Garner TW (2007) The relationship between the introduction of Batrachochytrium dendrobatidis, the international trade in amphibians and introduced amphibian species. Fungal Biol Rev 21:2-9

* Forrest MJ, Schlaepfer MA (2011) Nothing a hot bath won't cure: infection rates of amphibian chytrid fungus correlate negatively with water temperature under natural field settings. PLOS ONE 6:e28444

Frías-Alvarez P, Vredenburg VT, Familiar-López M, Longcore JE and others (2008) Chytridiomycosis survey in wild and captive Mexican amphibians. EcoHealth 5: 18-26

Greenspan SE, Calhoun AJ, Longcore JE, Levy MG (2012) Transmission of Batrachochytrium dendrobatidis to wood frogs (Lithobates sylvaticus) via a bullfrog ( $L$. catesbeianus) vector. J Wildl Dis 48:575-582

*Huss M, Huntley L, Vredenburg VT, Johns J, Green S (2013) Prevalence of Batrachochytrium dendrobatidis in 120 archived specimens of Lithobates catesbeianus (American bullfrog) collected in California, 1924-2007. EcoHealth 10:339-343

Hyatt AD, Boyle DG, Olsen V, Boyle DB and others (2007) Diagnostic assays and sampling protocols for the detection of Batrachochytrium dendrobatidis. Dis Aquat Org 73:175-192

Jennings MR, Hayes MP (1994) Amphibian and reptiles species of special concern in California. California Department of Fish and Game, Inland Fisheries Division, Rancho Cordova, CA

Johnson ML, Berger L, Philips L, Speare R (2003) Fungicidal effects of chemical disinfectants, UV light, desiccation and heat on the amphibian chytrid Batrachochytrium dendrobatidis. Dis Aquat Org 57:255-260

Johnson PTJ, McKenzie VJ, Peterson AC, Kerby JL, Brown J, Blaustein AR, Jackson T (2011) Regional decline of an iconic amphibian associated with elevation, land-use change, and invasive species. Conserv Biol 25:556-566

* Kinney VC, Heemeyer JL, Pessier AP, Lannoo MJ (2011) Seasonal pattern of Batrachochytrium dendrobatidis infection and mortality in Lithobates areolatus: affirmation of Vredenburg's '10,000 Zoospore Rule'. PLOS ONE 6:e16708

Kolby JE, Ramirez SD, Berger L, Griffin DW, Jocque M, Skerratt LF (2015) Presence of amphibian chytrid fungus (Batrachochytrium dendrobatidis) in rainwater suggests aerial dispersal is possible. Aerobiologia 31:411-419

Lannoo MJ, Petersen C, Lovich RE, Nanjappa P, Phillips C, Mitchell JC, Macallister I (2011) Do frogs get their kicks on Route 66 ? Continental US transect reveals spatial and temporal patterns of Batrachochytrium dendrobatidis infection. PLOS ONE 6:e22211

*Lips KR, Mendelson JR, Muñoz-Alonso A, CansecoMárquez L, Mulcahy DG (2004) Amphibian population declines in montane southern Mexico: resurveys of historical localities. Biol Conserv 119:555-564

* Luja VH, Rodríguez-Estrella R, Ratzlaff K, Parra-Olea G, Ramírez-Bautista A (2012) The chytrid fungus Batrachochytrium dendrobatidis in isolated populations of the Baja California treefrog Pseudacris hypochondriaca curta in Baja California Sur, Mexico. Southwest Nat 57: 323-327

*McMahon TA, Brannelly LA, Chatfield MW, Johnson PT and others (2013a) Chytrid fungus Batrachochytrium dendrobatidis has nonamphibian hosts and releases chemicals that cause pathology in the absence of infection. Proc Natl Acad Sci USA 110:210-215

McMahon TA, Romansic JM, Rohr JR (2013b) Nonmonotonic and monotonic effects of pesticides on the pathogenic fungus Batrachochytrium dendrobatidis in culture and on tadpoles. Environ Sci Technol 47:7958-7964

* Mendoza-Almeralla C, Burrowes P, Parra-Olea G (2015) La quitridiomicosis en los anfibios de México: una revisión. Rev Mex Biodivers 86:238-248

* Murrieta-Galindo R, Parra-Olea G, González-Romero A, López-Barrera F, Vredenburg VT (2014) Detection of Batrachochytrium dendrobatidis in amphibians inhabiting cloud forests and coffee agroecosystems in central Veracruz, Mexico. Eur J Wildl Res 60:431-439

Muths E, Corn PS, Pessier AP, Green DE (2003) Evidence for disease-related amphibian decline in Colorado. Biol Conserv 110:357-365

Olson DH, Aanensen DM, Ronnenberg KL, Powell CI and others (2013) Mapping the global emergence of Batrachochytrium dendrobatidis, the amphibian chytrid fungus. PLOS ONE 8:e56802

Padgett-Flohr GE (2008) Pathogenicity of Batrachochytrium dendrobatidis in two threatened California amphibians: Rana draytonii and Ambystoma californiense. Herpetol Conserv Biol 3:182-191

* Padgett-Flohr GE, Hopkins RL II (2009) Batrachochytrium dendrobatidis, a novel pathogen approaching endemism in central California. Dis Aquat Org 83:1-9

*Piovia-Scott J, Pope KL, Lawler SP, Cole EM, Foley JE (2011) Factors related to the distribution and prevalence of the fungal pathogen Batrachochytrium dendrobatidis in Rana cascadae and other amphibians in the Klamath Mountains. Biol Conserv 144:2913-2921

R Development Core Team (2016) R: a language and environment for statistical computing. R Foundation for Statistical Computing, Vienna. www.R-project.org

* Rachowicz LJ, Knapp RA, Morgan JA, Stice MJ, Vredenburg VT, Parker JM, Briggs CJ (2006) Emerging infectious disease as a proximate cause of amphibian mass mortality. Ecology 87:1671-1683

* Raffel TR, Halstead NT, McMahon TA, Davis AK, Rohr JR (2015) Temperature variability and moisture synergistically interact to exacerbate an epizootic disease. Proc R Soc B 282:20142039

Reeder NMM, Pessier AP, Vredenburg VT (2012) A reservoir species for the emerging amphibian pathogen Batrachochytrium dendrobatidis thrives in a landscape decimated by disease. PLOS ONE 7:e33567

Saenz D, Hall TL, Kwiatkowski MA (2015) Effects of urban- 
ization on the occurrence of Batrachochytrium dendrobatidis: do urban environments provide refuge from the amphibian chytrid fungus? Urban Ecosyst 18:333-340

Schaub DL, Larsen JH (1978) The reproductive ecology of the Pacific Treefrog (Hyla regilla). Herpetologica 34:409-416

Skerratt LF, Berger L, Speare R, Cashins S and others (2007) Spread of chytridiomycosis has caused the rapid global decline and extinction of frogs. EcoHealth 4:125-134

Stuart SN, Chanson JS, Cox NA, Young BE, Rodrigues AS, Fischman DL, Waller RW (2004) Status and trends of amphibian declines and extinctions worldwide. Science 306:1783-1786

Editorial responsibility: Douglas Woodhams, Boston, Massachusetts, USA
Vojar J, Havlíková B, Solsky M, Jablonski D, Ikovic V, Baláz V (2017) Distribution, prevalence, and amphibian hosts of Batrachochytrium dendrobatidis in the Balkans. Salamandra 53:44-49

Vredenburg VT, Knapp RA, Tunstall TS, Briggs CJ (2010) Dynamics of an emerging disease drive large-scale amphibian population extinctions. Proc Natl Acad Sci USA 107:9689-9694

Vredenburg VT, Felt SA, Morgan EC, McNally SVG, Wilson S, Green SL (2013) Prevalence of Batrachochytrium dendrobatidis in Xenopus collected in Africa (1871-2000) and in California (2001-2010). PLOS ONE 8:e63791

Submitted: July 3, 2017; Accepted: December 18, 2017 Proofs received from author(s): February 25, 2018 